\title{
PENGARUH KECERDASAN EMOSIONAL, KEPUASAN KERJA DAN KOMITMEN ORGANISASI TERHADAP KINERJA KARYAWAN PADA PT. SUPRA MATRA ABADI AEK NABARA KABUPATEN LABUHANBATU
}

\author{
Abd. Halim \\ Dosen Fakultas Ekonomi dan Bisnis (FEB) Labuhanbatu \\ Email: abdulhalimpsr89@gmail.com
}

\begin{abstract}
Abstrak
Tujuan dari penelitian ini adalah untuk mengetahui kecerdasan emosional, kepuasan kerja dan komitmen organisasi terhadap kinerja karyawan pada PT. Supra Matra Abadi Aek Nabara Kabupaten Labuhanbatu. Sampel penelitian ini berjumlah 87 orang karyawan. Pengumpulan data primer menggunakan kuesioner dan pengumpulan data skunder menggunakan studi pustaka. Metode analisis yang digunakan adalah analisis regresi linier berganda. Berdasarkan hasil hipotesis parsial (uji t) menunjukkan bahwa kecerdasan emosional berpengaruh positif dan signifikan terhadap kinerja karyawan pada PT. Supra Matra Abadi Aek Nabara Kabupaten Labuhanbatu, dimana nilai thitung $(6,235)>t_{\text {tabel }}(1,658)$ dan angka signifikansi 0,000 $<0,1$; kepuasan kerja berpengaruh positif dan signifikan terhadap kinerja karyawan pada PT. Supra Matra Abadi Aek Nabara Kabupaten Labuhanbatu, dimana nilai thitung $(5,593)>t_{\text {tabel }}(1,658)$ dan angka signifikansi 0,000 < 0,1; dan komitmen organisasi berpengaruh positif dan signifikan terhadap kinerja karyawan pada PT. Supra Matra Abadi Aek Nabara Kabupaten Labuhanbatu, dimana nilai thitung $(2,994)>t_{\text {tabel }}(1,658)$ dan angka signifikansi 0,004 < 0,1. Berdasarkan hasil uji hipotesis simultan (uji F) menunjukkan bahwa kecerdasan emosional, kepuasan kerja dan komitmen organisasi secara simultan berpengaruh positif dan signifikan terhadap kinerja karyawan pada PT. Supra Matra Abadi Aek Nabara Kabupaten Labuhanbatu. Kinerja karyawan dapat dijelaskan oleh kecerdasan emosional, kepuasan kerja, dan komitmen organisasi sebesar 65,4\%. Sedangkan sisanya 34,6\% dijelaskan oleh faktor-faktor lain yang tidak diteliti oleh penelitian ini, misalnya lingkungan kerja, iklim kerja, kepemimpinan, dan lain sebagainya.
\end{abstract}

\section{Kata Kunci: Kecerdasan Emosional, Kepuasan Kerja, Komitmen Organisasi, Kinerja Karyawan.}

\section{PENDAHULUAN}

\section{Latar Belakang Masalah}

Karyawan merupakan sumber daya manusia yang berharga dan mempunyai peranan penting baik secara perorangan maupun kelompok sebagai penggerak utama atas keberhasilan operasional kegiatan usaha, bahkan sukses tidaknya perusahaan ditentukan oleh keberadaan sumber daya manusianya. Oleh karena itu, sumber daya manusia harus selalu diperhatikan, dijaga dan dikembangkan.

Saat ini persaingan dalam dunia bisnis semakin kompetitif dan menuntut setiap organisasi untuk mengikuti perubahan yang terjadi dan menyesuaikannya ke dalam lingkungan internal organisasi. Usaha perubahan organisasi membutuhkan partisipasi dari semua karyawan. Untuk itu, perusahaan dituntut untuk meningkatkan kualitas sumber daya manusia sehingga terjadi peningkatan kinerja karyawan dan sekaligus dapat memberikan peningkatan kinerja perusahaan agar perusahaan tersebut dapat bertahan dan bersaing. 
Permasalahan mengenai kinerja karyawan merupakan permasalahan yang akan selalu dihadapi oleh pihak manajemen sebuah organisasi, seperti tidak tercapainya target produksi dan pekerjaan yang tidak diselelasikan tepat waktu, karena itu manajemen perlu mengetahui faktor-faktor yang dapat mempengaruhi kinerja karyawan. Faktor-faktor tersebut akan membuat manajemen perusahaan dapat mengambil berbagai kebijakan yang diperlukan, sehingga dapat meningkatkan kinerja karyawan sesuai harapan.

Salah satu faktor penting yang layak memperoleh prioritas bagi segenap karyawan untuk meningkatkan kinerja adalah dengan memunculkan kemampuan motivasi diri sendiri, mengatasi frustasi, mengontrol desakan hati, mengatur suasana hati, berempati, dan kemampuan bekerja sama. Hal-hal tersebut mengacu pada kemampuan karyawan dalam mengendalikan emosinya yang dapat disebut dengan kecerdasan emosional (emotional quotient). Untuk mencapai kesuksesan dalam dunia kerja bukan hanya kemampuan kognitif saja yang dibutuhkan tetapi juga kemampuan emosional. Oleh karena itu, pimpinan dan manajer jika mengharapkan pencapaian kinerja maksimal, upaya paling tepat bagaimana membina diri dan sumber daya manusia bawahan untuk memiliki kecerdasan emosional karyawan.

Selain kecerdasan emosional, kepuasan kerja juga merupakan salah satu faktor yang mempengaruhi kinerja karyawan. Kepuasan kerja (job satisfaction) pada dasarnya merupakan pernyataan emosional yang positif atau menyenangkan sebagai dampak dari apresiasi karyawan terhadap pekerjaan dan pengalaman kerja tertentu. Kepuasan kerja juga merupakan satu faktor penting dalam upaya meningkatkan kinerja, oleh karena itu setiap perusahaan perlu berusaha agar karyawan mempunyai kinerja yang tinggi.

Apabila karyawan puas terhadap pekerjaannya karyawan akan lebih giat dalam melaksanakan tugas yang diberikan kepadanya. Karyawan yang memiliki perilaku puas terhadap pekerjaannya biasanya memiliki ciri mereka lebih senang dalam melakukan pekerjaannya dan akan bekerja dengan semangat kerja tinggi sehingga kinerja karyawan tersebut tinggi. Dimana hal tersebut akan mempunyai dampak langsung ataupun tidak langsung terhadap efektivitas organisasi perusahaan.

Kepuasan kerja yang tinggi akan menghasilkan kinerja karyawan yang baik. Perusahaan yang mampu meningkatkan kinerja karyawannya, akan memperoleh banyak keuntungan karena kinerja karyawan yang tinggi pekerjaan akan lebih cepat diselesaikan, kerusakan dapat dikurangi, tingkat absensi dapat diperkecil, dan kemungkinan perpindahan karyawan dapat diperkecil. Hal tersebut juga dapat memberikan dampak pada peningkatan kinerja perusahaan.

Dalam suatu perusahaan, salah satu hal yang paling dikhawatirkan adalah kinerja perusahaan tersebut yang terus menurun akibat rendahnya kepuasan kerja. Kepuasan kerja yang rendah dapat mengakibatkan kinerja karyawan turun bahkan akan terjadi pemogokan, pelambanan kerja, ketidakhadiran atau pergantian karyawan. Oleh karena itu, perusahaan hendaknya memberikan perhatian terhadap kepuasan kerja karyawannya.

Kinerja Karyawan juga dapat dipengaruhi oleh komitmen organisasi karyawan. Komitmen organisasi yang tinggi dapat memperkuat atau meningkatkan kinerja karyawan. Komitmen karyawan terhadap perusahaan atau biasa disebut menunjukkan keyakinan karyawan untuk menerima tujuan organisasi sehingga bekeinginan untuk tetap tinggal dan menjadi bagian dari organisasi tersebut.

Karyawan yang berkomitmen akan cenderung lebih bertanggung jawab dalam pekerjaannya. Karyawan yang mempunyai komitmen terhadap organisasinya juga akan mengembangkan pola pandang yang lebih positif terhadap organisasi dan dengan senang hati tanpa paksaan mengeluarkan energi ekstra demi kepentingan organisasi. Hal tersebut 
menunjukkan bahwa komitmen organisasi memiliki arti lebih dari sekedar loyalitas yang pasif, tetapi melibatkan hubungan aktif dan keinginan karyawan untuk memberikan kontribusi yang berarti pada organisainya. Kontribusi yang diberikan karyawan secara totalitas otomatis akan meningkatkan kinerjanya.

PT. Supra Matra Abadi sebagai salah satu perusahaan yang bergerak di bidang usaha perkebunan dan pengelolaan hasil perkebunan tidak luput dari permasalahan penurunan kinerja karyawan yang disebabkan oleh kecerdasan emosional yang rendah. Dari hasil observasi yang telah dilakukan oleh peneliti pada karyawan di PT. Supra Matra Abadi Aek Nabara, peneliti melihat bahwa beberapa karyawan masih memiliki empati yang rendah, terlihat dari karyawan yang stres dengan pekerjaannya dan merokok di dalam ruangan kantor yang tentunya akan mengganggu konsentrasi karyawan lain. Hal tersebut menunjukkan kurangnya kecerdasan emosional karyawan.

Kepuasan kerja karyawan PT. Supra Matra Abadi Aek Nabara rata-rata sudah tergolong baik, namun terlihat terjadi penurunan kepuasan kerja pada beberapa karyawan yang menyebabkan penurunan kinerja karyawan. Turunnya kepuasan karyawan tersebut dapat dilihat dari meningkatnya tingkat pelanggaran yang dilakukan oleh karyawan seperti karyawan yang malas bekerja dan malah berbincang-bincang di jam kerja. Peneliti melihat hal tersebut terjadi karena masih kurangnya pengawasan dari atasan yang mengakibatkan karyawan merasa kesulitan mengerjakan pekerjaan yang sulit sehingga kepuasannya terhadap pekerjaan menurun.

Dari hasil observasi beberapa karyawan PT. Supra Matra Abadi Aek Nabara, peneliti melihat indikasi rendahnya tingkat komitmen organisasi karyawan. Hal ini terlihat dari tingkat absen yang tinggi. Semakin meningkatnya jumlah karyawan yang tidak masuk kerja baik karena sakit, ijin atau tanpa keterangan akan menyebabkan pekerjaan tidak selesai dalam waktu yang ditentukan, hal tersebut menunjukkan telah terjadinya penurunan kinerja karyawan.

Seperti uraian diatas sebelumnya, bahwa kecerdasan emosional, kepuasan kerja, dan komitmen organisasi karyawan yang rendah akan berdampak pada kinerja karyawan. Kinerja karyawan yang rendah akan memberikan banyak dampak negatif bagi perusahaan. PT. Supra Matra Abadi Aek Nabara juga tidak lepas dari permasalahan mengenai kinerja karyawan yang menyangkut ketiga aspek tersebut.

\begin{tabular}{ccccc}
\multicolumn{5}{c}{ Tabel 1.1 } \\
\multicolumn{5}{c}{ Penilaian Kinerja Karyawan PT. SMA Tahun 2018} \\
Nilai & Klasifikasi & Keterangan & Jumlah & Persentase \\
$90-100$ & A & Istimewa & 46 & $6,97 \%$ \\
$80-89$ & B & Sangat Baik & 112 & $16,97 \%$ \\
$70-79$ & C & Baik & 387 & $58,63 \%$ \\
$60-69$ & D & Cukup & 76 & $100,52 \%$ \\
$\leq 59$ & E & Kurang & 39 & $5,91 \%$ \\
& Total & & $\mathbf{6 6 0}$ & $\mathbf{1 0 0 \%}$
\end{tabular}

Sumber : PT. SMA Aek Nabara (2019)

Berdasarkan Tabel 1.1 dapat dilihat bahwa pada tahun 2018 persentase hasil kinerja karyawan secara umum sudah baik. Namun masih ada beberapa karyawan yang menunjukkan kinerja dibawah standar. Terlihat bahwa terdapat 76 orang karyawan yang hanya dapat memenuhi kategori cukup, dan bahkan masih ada 39 orang karyawan yang kinerjanya dikategorikan kurang. Hal tersebut menunjukkan bahwa PT. Supra Matra Abadi Aek Nabara masih perlu melakukan peningkatan dan perbaikan terhadap kinerja karyawannya. 


\section{TINJAUAN PUSTAKA}

\subsection{Kecerdasan Emosional}

Menurut Cooper dan Sawaf (dalam Sihombing, 2017) bahwa (kecerdasan emosional) adalah kemampuan untuk merasakan, memahami, dan secara selektif menerapkan daya dan kepekaan emosi sebagai sumber energi dan pengaruh manusia. Kecerdasan emosional membutuhkan perasaan pengawasan, belajar mengenali, menghargai perasaan dalam diri mereka sendiri dan orang lain dan merespon dengan tepat, efektif menerapkan energi emosional dalam kehidupan sehari-hari. Menurut Wirawan (2010) kecerdasan emosional merupakan kemampuan untuk me-manage emosi diri sendiri dan kemampuan untuk memanajemeni emosi orang lain.

\subsection{Kepuasan Kerja}

Mangkunegara (2013) menyatakan kepuasan kerja adalah suatu perasaan yang menyokong atau tidak menyokong diri pegawai yang berhubungan dengan pekerjaannya maupun dengan kondisi dirinya. Menurut Sutrisno (2010) kepuasan kerja adalah suatu sikap karyawan terhadap pekerjaan yang berhubungan dengan situasi kerja, kerjasama antar karyawan, imbalan yang diterima dalam kerja, dan hal-hal yang menyangkut faktor fisik dan psikologis.

\subsection{Komitmen Organisasi}

Menurut Wibowo (2012) komitmen organisasi mencerminkan tingkatan dimana individu mengidentifikasi dengan organisasi dan mempunyai komitmen terhadap tujuaanya. Menurut Robbins dan Coulter (2010) komitmen organisasi adalah derajat dimana seorang karyawan mengidentifikasikan dirinya dengan organisasi tertentu beserta tujuannya dan berkeinginan untuk mempertahankan keanggotaannya di dalam organisasi tersebut.

\subsection{Kinerja Karyawan}

Menurut Mangkunegara kinerja (2013) adalah hasil kinerja secara kualitas dan kuantitas yang dicapai oleh seorang pegawai dalam melaksanakan tugasnya sesuai dengan tanggungn jawab yang diberikan kepadanya. Menurut Sedarmayanti (2011) mengungkapkan bahwa kinerja merupakan terjemahan dari performance yang berarti hasil kerja seorang pekerja, sebuah proses manajemen atau suatu organisasi secara keseluruhan, dimana hasil kerja tersebut harus dapat ditunjukkan buktinya secara konkrit dan dapat diukur.

\subsection{Kerangka Konseptual}

Kerangka konseptual dari penelitian ini adalah:

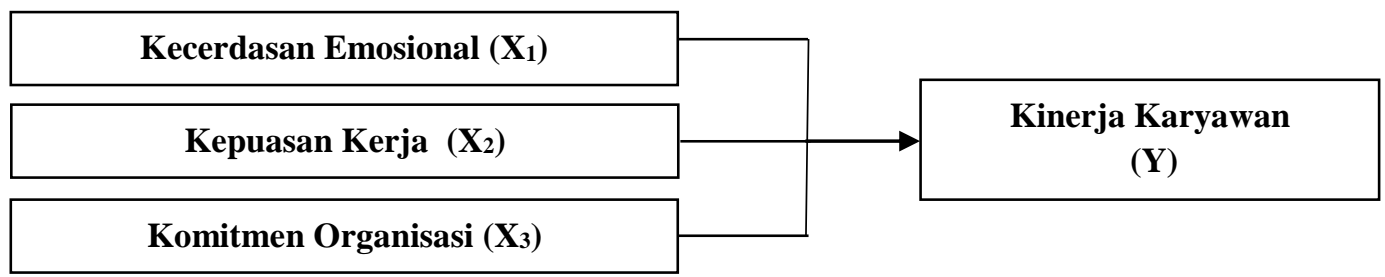

Gambar 2.1 Kerangka konseptual 


\subsection{Hipotesis}

Hipotesis merupakan jawaban sementara terhadap rumusan masalah penelitian (Sugiyono, 2012). Berdasarkan perumusan masalah dan kerangka konseptual, maka hipotesis dalam penelitian ini adalah :

1) Kecerdasan Emosional berpengaruh positif dan signifikan terhadap kinerja karyawan pada PT. Supra Matra Abadi Aek Nabara.

2) Kepuasan Kerja berpengaruh positif dan signifikan terhadap kinerja karyawan pada PT. Supra Matra Abadi Aek Nabara.

3) Komitmen Organisasi berpengaruh positif dan signifikan terhadap kinerja karyawan pada PT. Supra Matra Abadi Aek Nabara.

4) Kecerdasan Emosional, kepuasan kerja dan komitmen organisasi secara simultan berpengaruh positif dan signifikan terhadap kinerja karyawan pada PT. Supra Matra Abadi Aek Nabara.

\section{METODE PENELITIAN}

\subsection{Jenis Penelitian}

Jenis penelitian yang digunakan dalam penelitian ini adalah penelitian assosiatif, yakni penelitian yang menghubungkan antara dua variabel atau lebih Sugiyono (2012). Dengan hubungan kausal yaitu hubungan yang bersifat sebab akibat Sugiyono (2012). Tempat dan waktu penelitian ini dilakukan di PT. Supra Matra Abadi yang berlokasi di Desa S-5 Aek Nabara Kecamatan Bilah Hulu Kabupaten Labuhanbatu.

\subsection{Batasan Operasional}

Batasan operasional variabel digunakan untuk menghindari kesimpangsiuran dalam membahas dan menganalisa permasalahan dalam penelitian ini. Oleh karena itu, dibuat suatu batasan operasional antara lain:

1. Variabel bebas (Independent Variable) terdiri dari:

Kecerdasan Emosional $\left(\mathrm{X}_{1}\right)$, Kepuasan Kerja $\left(\mathrm{X}_{2}\right)$, Komitmen Organisasi $\left(\mathrm{X}_{3}\right)$.

2. Variabel terikat (Dependent Variable) terdiri dari:

Kinerja Karyawan (Y)

\subsection{Populasi}

Kuncoro (2009) populasi adalah kelompok elemen yang lengkap, yang biasanya berupa orang, objek, transaksi, atau kejadian dimana kita tertarik untuk mempelajarinya atau menjadi objek penelitian. Objek dalam penelitian ini adalah karyawan kebun PT. Supra Matra Abadi yang berjumlah 87 orang.

\subsection{Sampel}

Sampel adalah suatu bagian dari sampel yang akan diteliti dan dianggap yang dapat menggambarkan populasinya (Situmorang dkk, 2012). Metode pengambilan sampel menggunakan sensus dan mengambil sampel dari seluruh populasi (sampel jenuh) Jumlah karyawan PT. Supra Matra Abadi sebanyak 87 orang.

\subsection{Jenis Data dan Sumber Data}

Menurut Situmorang dkk, (2012) cara memperolehnya data terbagi dua berdasar pada sumbernya yaitu: 1) Data primer (Primary Data) yaitu data yang dikumpulkan sendiri oleh perorangan/suatu organisasi secara langsung dari objek yang diteliti dan untuk kepentingan studi yang bersangkutan yang dapat berupa interview, kuesioner dan observasi. Data primer 
diperoleh dengan memberikan daftar pernyataan (kuesioner) kepada karyawan kebun PT. Supra Matra Abadi. 2) Data sekunder (Secondary Data) yaitu data yang diperoleh atau dikumpulkan dan disatukan oleh studi-studi sebelumnya atau yang diterbitkan oleh berbagai instansi lain. Biasanya sumber tidak langsung berupa data dokumentasi dan arsip-arsip resmi.

\subsection{Metode dan Teknik Pengumpulan Data}

Dalam penelitian ini, metode pengumpulan data yang digunakan adalah metode kuesioner, jenis kuesioner ini adalah kuesioner tertutup dengan skala likert. Teknik pengumpulan data dalam penelitian ini adalah kuesioner dan wawancara. Teknik pengumpulan data meliputi:

a. Wawancara (Interview), digunakan sebagai teknik pengumpulan data apabila peneliti ingin melakukan studi pendahuluan untuk menemukan permasalah yang harus diteliti, dan juga apabila peneliti ingin mengetahui hal-hal dari responden yang lebih mendala dan jumlah respondennya sedikit atau kecil. Teknik pengumpulan data ini mendasarkan diri pada laporan tentang diri sendiri atau self report, atau setidak-tidaknya pada pengetahuan atau keyakinan pribadi, Sugiyono (2012).

b. Kuesioner, merupakan teknik pengumpulan data yang dilakukan dengan cara memberi seperangkat pertanyaan atau pernyataan tertulis kepada responden untuk dijawabnya. Kuesioner merupakan teknik pengumpulan data yang efisien bila peneliti tahu dengan pasti variable yang akan diukur dan tahu apa yang bisa diharapkan dari responden. Selain itu kuesioner juga cocok digunakan bila jumlah responden cukup besar dan tersebar di wilayah yang luas. Kuesioner dapat berupa pertanyaan/pernyataan tertutup atau terbuka, dapat diberikan kepada responden secara langsung atau dikirim melalui pos atau internet, Sugiyono (2012).

c. Observasi (Pengamatan) merupakan cara memperoleh data dengan mengamati (perilakubukan perilaku dari) subyek penelitian dan merekam jawabannya untuk dianalisis. Metode dalam observasi bisa dalam bentuk struktur dan tidak struktur. Dalam observasi bentuk struktur, peneliti merinci secara detail sesuatu yang akan diamati dan bagaimana pengukuran dapat direkam. Dalam observsi bentuk tidak struktur, peneliti berupaya mengamati segala aspek fenomena yang berkaitan atau relevan dengan masalah yang sedang ditangani, Wijaya, (2013).

\section{HASIL PENELITIAN DAN PEMBAHASAN}

\subsection{Analisis Regresi Linear Berganda}

Analisis regresi linear berganda berfungsi untuk mengetahui pengaruh variabel bebas (independent variable) yaitu Kecerdasan Emosional $\left(\mathrm{X}_{1}\right)$, Kepuasan Kerja $\left(\mathrm{X}_{2}\right)$, Komitmen Organisasi $\left(\mathrm{X}_{3}\right)$ terhadap variabel terikat (dependent variable) yaitu Kinerja Karyawan $(\mathrm{Y})$. Analisis regresi linier berganda dalam penelitian ini menggunakan software SPSS for windows. Perhitungan persamaan regresi linear berganda adalah sebagai berikut :

$$
\mathbf{Y}=\mathbf{a}+\mathbf{b}_{1} \mathbf{X}_{1}+\mathbf{b}_{2} \mathbf{X}_{2}+\mathbf{b}_{3} \mathbf{X}_{3}+\mathbf{e}
$$


Tabel 4.1. Hasil Regresi Linear Berganda

Coefficients $^{\mathrm{a}}$

\begin{tabular}{|c|c|c|c|c|c|c|}
\hline \multicolumn{2}{|c|}{ Model } & \multicolumn{2}{|c|}{$\begin{array}{l}\text { Unstandardized } \\
\text { Coefficients }\end{array}$} & \multirow{2}{*}{$\begin{array}{c}\begin{array}{c}\text { Standardized } \\
\text { Coefficients }\end{array} \\
\text { Beta }\end{array}$} & \multirow[t]{2}{*}{$\mathrm{t}$} & \multirow[t]{2}{*}{ Sig. } \\
\hline & & B & Std. Error & & & \\
\hline \multirow{4}{*}{1} & (Constant) & 1,961 & 1,476 & & 1,329 & 187 \\
\hline & Kecerdasan Emosional & ,394 & ,063 & ,456 & 6,235 & ,000 \\
\hline & Kepuasan Kerja &, 321 & ,057 & ,397 & 5,593 & ,000 \\
\hline & Komitmen Organisasi & ,184 & ,062 & ,203 & 2,994 & ,004 \\
\hline
\end{tabular}

a. Dependent Variable: Kinerja Karyawan

b. Sumber : Hasil Penelitian (2019)

Dari Tabel 4.1 diketahui kolom Unstandardized Coefficients pada bagian b diperoleh nilai $b_{1}$ Kecerdasan Emosional sebesar 0,394, b $_{2}$ Kepuasan Kerja sebesar 0,321, dan b $_{3}$ Komitmen Organisasi sebesar 0,184, dan nilai konstanta (a) adalah 1,961 maka diperoleh persamaan regresi linier berganda sebagi berikut:

$$
Y=1,961+0,394 X_{1}+0,321 X_{2}+0,184 X_{3}+e
$$

Persamaan regresi linier berganda tersebut dapat diuraikan sebagai berikut:

a. Konstanta (a) = 1,961, artinya jika variabel bebas yaitu Kecerdasan Emosional $\left(\mathrm{X}_{1}\right)$, Kepuasan Kerja $\left(\mathrm{X}_{2}\right)$, Komitmen Organisasi $\left(\mathrm{X}_{3}\right)$, bernilai nol, maka Kinerja Karyawan di PT. Supra Matra Abadi tetap sebesar 1,961.

b. Koefisien regresi $\mathrm{X}_{1}\left(\mathrm{~b}_{1}\right)=0,394$, artinya jika faktor Kecerdasan Emosional di tingkatkan sebesar satu satuan maka Kinerja Karyawan di PT. Supra Matra Abadi akan naik sebesar 0,394 satuan.

c. Koefisien regresi $\mathrm{X}_{2}\left(\mathrm{~b}_{2}\right)=0,321$, artinya jika variabel Kepuasan Kerja di tingkatkan sebesar satu satuan maka Kinerja Karyawan di PT. Supra Matra Abadi akan naik sebesar 0,321 satuan.

d. Koefisien regresi $\mathrm{X}_{3}\left(\mathrm{~b}_{3}\right)=0,184$, artinya jika variabel Komitmen Organisasi di tingkatkan sebesar satu satuan maka Kinerja Karyawan di PT. Supra Matra Abadi akan naik sebesar 0,184 satuan.

\subsection{Koefisien Determinasi $\left(\mathbf{R}^{\mathbf{2}}\right)$}

Koefisien determinasi menunjukkan besar kecilnya kontribusi pengaruh variabel bebas Kecerdasan Emosional $\left(\mathrm{X}_{1}\right)$, Kepuasan Kerja $\left(\mathrm{X}_{2}\right)$, Komitmen Organisasi $\left(\mathrm{X}_{3}\right)$, terhadap variabel terikat Kinerja Karyawan (Y), dimana $0 \leq \mathrm{R}^{2} \leq 1$. Bila nilai $\mathrm{R}^{2}$ semakin mendekati nilai 1 maka menunjukkan semakin kuatnya hubungan variabel bebas terhadap variabel terikat. Dan sebaliknya, jika determinan $\left(\mathrm{R}^{2}\right)$ semakin kecil atau mendekati nol, maka pengaruh variabel bebas terhadap variabel terikat semakin lemah. Hasil pengolahan dari analisis regresi linier berganda dapat dilihat pada tabel 4.2 berikut ini: 
P-ISSN : 2477-6092

E-ISSN : 2620-3391
JURNAL ECOBISMA

VOL. 7 NO. 1 TAHUN 2020

Tabel 4.2. Koefisien Determinasi $\left(\mathbf{R}^{2}\right)$

Model Summary

\begin{tabular}{|c|r|r|r|r|}
\hline Model & \multicolumn{1}{|c|}{$\mathbf{R}$} & $\boldsymbol{R}$ Square & $\begin{array}{c}\text { Adjusted } \boldsymbol{R} \\
\text { Square }\end{array}$ & $\begin{array}{c}\text { Std. Error of } \\
\text { the Estimate }\end{array}$ \\
\hline 1 &, $816^{\mathrm{a}}$ &, 666 &, 654 &, 908 \\
\hline
\end{tabular}

Predictors: (Constant), Kecerdasan Emosional, Kepuasan Kerja, Komitmen Organisasi,

Tabel 4.2 menunjukkan bahwa:

a. $\quad \mathrm{R}=0,816$ berarti hubungan variabel Kecerdasan Emosional, Kepuasan Kerja dan Komitmen Organisasi terhadap Kinerja Karyawan sebesar 81,6\%. Artinya memiliki hubungan yang erat.

b. $\quad R$ Square sebesar 0,666 berarti $66,6 \%$ faktor-faktor Kinerja Karyawan di PT. Supra Matra Abadi dapat dijelaskan oleh Kecerdasan Emosional, Kepuasan Kerja dan Komitmen Organisasi. Sedangkan sisanya 33,4\% dapat dijelaskan oleh faktor-faktor lain yang tidak diteliti dalam penelitian ini.

c. Ajusted $R$ Square sebesar 0,654 berarti 65,4\% faktor-faktor Kinerja Karyawan di PT. Supra Matra Abadi dapat dijelaskan oleh Kecerdasan Emosional, Kepuasan Kerja dan Komitmen Organisasi. Sedangkan sisanya 34,6\% dapat dijelaskan oleh faktor-faktor lain yang tidak diteliti oleh peneliti lain.

d. Standard Error of Estimated adalah 0,908 semakin kecil standar deviasi berarti model semakin baik.

\subsection{Uji Hipotesis dengan Menggunakan Analisis Regresi Linear Berganda}

Untuk menguji apakah hipotesis yang diajukan diterima atau ditolak digunakan statistik $\mathrm{t}$ (uji t). Pengujian ini dilakukan untuk mengetahui seberapa besar pengaruh variabel bebas yaitu Kecerdasan Emosional $\left(\mathrm{X}_{1}\right)$, Kepuasan Kerja $\left(\mathrm{X}_{2}\right)$, dan Komitmen Organisasi $\left(\mathrm{X}_{3}\right)$ secara parsial terhadap variabel terikat yaitu Kinerja Karyawan (Y). Hasil pengolahan dari Uji T dapat dilihat pada tabel 4.3 sebagai berikut:

Tabel 4.3. Hasil Uji T

Coefficients $^{\mathrm{a}}$

\begin{tabular}{|c|c|c|c|c|c|c|}
\hline \multicolumn{2}{|c|}{ Model } & \multicolumn{2}{|c|}{$\begin{array}{c}\text { Unstandardized } \\
\text { Coefficients }\end{array}$} & $\begin{array}{l}\text { Standardized } \\
\text { Coefficients }\end{array}$ & \multirow[t]{2}{*}{$\mathrm{t}$} & \multirow[t]{2}{*}{ Sig. } \\
\hline & & B & Std. Error & Beta & & \\
\hline \multirow{4}{*}{1} & (Constant) & 1,961 & 1,476 & & 1,329 & , 187 \\
\hline & Kecerdasan Emosional &, 394 &, 063 & ,456 & 6,235 &, 000 \\
\hline & Kepuasan Kerja & ,321 &, 057 & ,397 & 5,593 &, 000 \\
\hline & Komitmen Organisasi & 184 & ,062 & 203 & 2,994 & ,004 \\
\hline
\end{tabular}

c. Dependent Variable: Kinerja Karyawan

d. Sumber : Hasil Penelitian (2019)

\subsubsection{Hasil Pengujian Hipotesis Pertama $\left(\mathrm{X}_{1}\right)$}

Terlihat pada kolom $\mathrm{T}$ variabel Kecerdasan Emosional $\left(\mathrm{X}_{1}\right)$ mempunyai nilai thitung $(6,235)>t_{\text {tabel }}(1.658)$ yang berarti Ho ditolak dan Ha diterima. Sedangkan nilai signifikan lebih kecil dari nilai probabilitas 0,1 atau nilai signifikan $0,000<0,1$. Dengan demikian dapat disimpulkan variabel Kecerdasan Emosional $\left(\mathrm{X}_{1}\right)$ berpengaruh positif dan signifikan terhadap Kinerja Karyawan di PT. Supra Matra Abadi pada $\alpha=10 \%$. Artinya jika ditingkatkan variabel Kecerdasan Emosional sebesar satu satuan maka Kinerja Karyawan akan meningkat 
sebesar 0,394 satuan. Nilai t positif menunjukkan bahwa variabel Kecerdasan Emosional mempunyai hubungan yang searah dengan Kinerja Karyawan.

\subsubsection{Hasil Pengujian Hipotesis Kedua $\left(\mathrm{X}_{2}\right)$}

Pada kolom $T$ variabel Kepuasan Kerja $\left(X_{2}\right) t_{\text {hitung }}(5,593)>t_{\text {tabel }}(1,658)$ yang berarti Ho ditolak dan Ha diterima. Sedangkan nilai signifikan lebih kecil dari nilai probabilitas 0,1 atau nilai signifikan $0,000<0,1$. Dengan demikian dapat disimpulkan variabel Kepuasan Kerja $\left(\mathrm{X}_{2}\right)$ berpengaruh positif dan signifikan terhadap Kinerja Karyawan di PT. Supra Matra Abadi pada $\alpha=10 \%$. Artinya jika ditingkatkan variabel Kepuasan Kerja sebesar satu satuan maka Kinerja Karyawan akan meningkat sebesar 0,321 satuan. Nilai t positif menunjukkan bahwa variabel Kepuasan Kerja mempunyai hubungan yang searah dengan Kinerja Karyawan.

\subsubsection{Hasil Pengujian Hipotesis Ketiga $\left(X_{3}\right)$}

Pada kolom $T$ variabel Komitmen Organisasi $\left(X_{3}\right) t_{\text {hitung }}(2,994)>t_{\text {tabel }}(1,658)$ yang berarti Ho ditolak dan Ha diterima. Sedangkan nilai signifikan lebih kecil dari nilai probabilitas 0,1 atau nilai signifikan $0,004<0,1$. Dengan demikian dapat disimpulkan variabel Komitmen Organisasi $\left(\mathrm{X}_{3}\right)$ berpengaruh positif dan signifikan terhadap Kinerja Karyawan di PT. Supra Matra Abadi pada $\alpha=10 \%$. Artinya jika ditingkatkan variabel Komitmen Organisasi sebesar satu satuan maka Kinerja Karyawan akan meningkat sebesar 0,184 satuan. Nilai t positif menunjukkan bahwa variabel Komitmen Organisasi mempunyai hubungan yang searah dengan Kinerja Karyawan.

\subsubsection{Hasil Pengujian Hipotesis $X_{1}, X_{2}, X_{3}$.}

Uji signifikasi simultan (uji F) digunakan untuk membuktikan pengaruh kecerdasan emosional, kepuasan kerja dan komitmen organisasi secara bersama-sama (simultan) terhadap kinerja karyawan pada PT. Supra Matra Abadi Aek Nabara Kabupaten Labuhanbatu.

\section{Tabel 4.4}

Hasil Uji Simultan (Uji F)

Anova $^{a}$

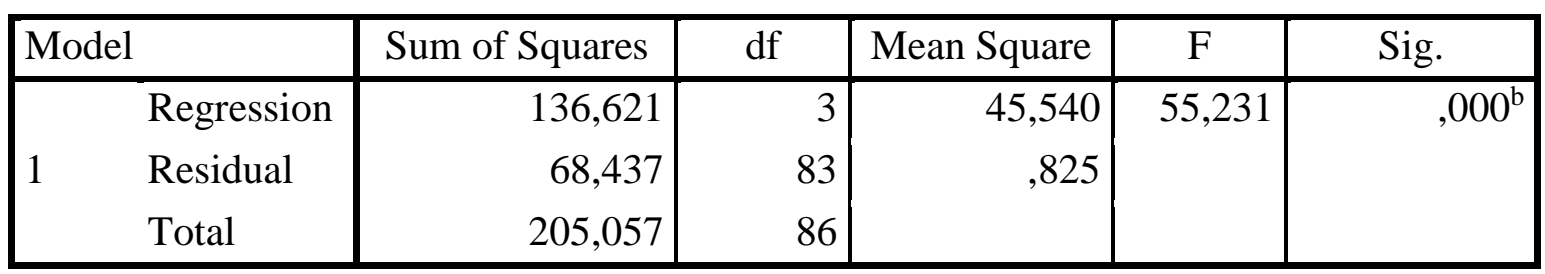

a. Dependent Variable: Kinerja

b. Predictors: (Constant), Komitmen Organisasi, Kepuasan Kerja, Kecerdasan Emosional Sumber : Hasil Penelitian (2019)

Untuk menentukan nilai $\mathrm{F}_{\text {tabel }}$ digunakan derajat kebebasan (df) yaitu df $1=k-1$ dan df $2=n-k$, dimana $k$ adalah jumlah variabel dan $n$ adalah jumlah sampel. Maka diperoleh df $1=k-1=4-1=3$ dan df $2=n-\mathrm{k}=87-4=83$ pada $\alpha=0,1$. Maka nilai $\mathrm{F}_{\text {tabel }}(\mathrm{df} 1=3$ dan $\mathrm{df} 2=83$ ) adalah 2,930 .

Selanjutnya perbandingan nilai $F_{\text {hitung }}$ dengan $F_{\text {tabel }}$ menunjukkan $F_{\text {hitung }}(55,231)>F_{\text {tabel }}$ $(2,930)$ dengan taraf signifikansi $0,000<0,1$. Hasil ini berarti bahwa kecerdasan emosional, kepuasan kerja dan komitmen organisasi secara simultan (bersama-sama) berpengaruh positif 
dan signifikan terhadap kinerja karyawan pada PT. Supra Matra Abadi Aek Nabara Kabupaten Labuhanbatu. Dengan demikian hipotesis diterima.

\subsection{Pembahasan Hasil Penelitian}

Sesuai dengan hasil jawaban responden atas pernyataan-pernyataan yang ditujukan terkait dengan variabel-variabel yang diteliti dalam penelitian, dan hasil pengujian secara statistik terhadap hipotesis yang diajukan, maka dapat disesuaikan beberapa hal yang merupakan temuan-temuan dalam penelitian.

\subsubsection{Pengaruh Kecerdasan Emosional Terhadap Kinerja Karyawan}

Berdasarkan hasil penelitian yang dilakukan terhadap 87 responden pada karyawan PT. Supra Matra Abadi Aek Nabara Kabupaten Labuhanbatu, hasil analisis regresi linier berganda pada koefisien regresi menunjukkan bahwa variabel kecerdasan emosional berpengaruh positif terhadap kinerja karyawan. Selain itu melalui uji t diketahui bahwa kecerdasan emosional berpengaruh signifikan terhadap kinerja karyawan yang ditandai dengan nilai thitung $(6,235)>t_{\text {tabel }}(1,658)$ dan angka signifikansi $0,000<0,1$. Artinya apabila karyawan yang memiliki kecerdasan emosional yang semakin baik maka kinerja karyawan juga akan meningkat pula.

Kecerdasan emosional karyawan didukung oleh beberapa faktor seperti faktor psikologis karyawan yang berasal dari dalam diri karyawan seperti kesadaran diri akan kemampuan diri, kemampuan untuk mengendalikan emosi dan beradaptasi, kemampuan memotiviasi diri dan bersikap optimis, kemampuan memahami perasaan orang lain, dan memiliki kemampuan berkomunikasi dengan baik. Hal tersebut akan mengkoordinasikan diri karyawan agar mampu berperilaku secara efektif. Faktor lainnya adalah kebiasaan, dengan selalu berperilaku secara efektif akan membuat karyawan menjadi terbiasa melakukannya. Karyawan PT. Supra Matra Abadi memiliki kecerdasan emosional yang tergolong bagus karena memiliki rata-rata jawaban yang menginterpretasikan bahwa sebagian besar karyawan setuju terhadap pernyataan dalam variabel kecerdasan emosional.

Hasil penelitian ini juga sesuai dengan penelitian terdahulu Florida (2014) dan Sukmawati dan Gani (2014) yang menyatakan bahwa secara parsial kecerdasan emosional berpengaruh positif dan signifikan terhadap kinerja karyawan. Semakin baik kecerdasan emosional karyawan, semakin tinggi kinerja karyawan tersebut.

\subsubsection{Pengaruh Kepuasan Kerja Terhadap Kinerja Karyawan}

Hasil penelitian ini menunjukkan bahwa kepuasan kerja terbukti membawa pengaruh yang signifikan terhadap kinerja karyawan. Hal tersebut dapat dilihat berdasarkan hasil analisis regresi linier berganda pada koefisien regresi yang menunjukkan bahwa variabel kepuasan kerja berpengaruh positif terhadap kinerja karyawan. Melalui uji t diketahui bahwa kepuasan kerja berpengaruh positif signifikan terhadap kinerja karyawan yang ditandai dengan nilai thitung $(5,593)>t_{\text {tabel }}(1,658)$ dan angka signifikansi $0,000<0,1$. Artinya karyawan yang puas terhadap pekerjaannya terbukti membawa pengaruh yang signifikan terhadap kinerja karyawan pada PT. Supra Matra Abadi Aek Nabara Kabupaten Labuhanbatu.

Kepuasan kerja karyawan dapat meningkat dengan dipengaruhi beberapa faktor seperti pekerjaan itu sendiri apakah sesuai dengan minat dan kemampuan karyawan, imbalan yang diterima karyawan apakah sudah sesuai dengan beban kerjanya, kesempatan promosi yang dirasa adil oleh karyawan, pengawasan atasan berupa bantuan teknis, dan rekan kerja yang mendukung dan kooperatif. Hasil pengamatan mengindikasikan adanya kecenderungan bahwa kepuasan kerja karyawan yang tinggi memiliki tingkat kinerja yang lebih tinggi. Hasil 
penelitian ini membuktikan adanya bukti konkrit hubungan kedua variabel. Dalam kondisi ini upaya peningkatan kinerja karyawan bisa dilakukan dengan meningkatkan kepuasan kerja karyawan.

Hasil penelitian ini tidak sejalan dengan penelitian terdahulu Florida (2014) dalam penelitiannya yang menyatakan bahwa kepuasan kerja tidak mempunyai pengaruh yang signifikan tetapi positif terhadap kinerja karyawan.

\subsubsection{Pengaruh Komitmen Organisasi Terhadap Kinerja Karyawan}

Hasil penelitian ini menunjukkan bahwa komitmen organisasi terbukti berpengaruh positif dan signifikan terhadap kinerja karyawan. Hal tersebut dapat dilihat dari hasil analisis regresi linier berganda pada koefisien regresi menunjukkan hasil yang positif. Selain itu melalui uji t diketahui bahwa komitmen organisasi berpengaruh signifikan terhadap kinerja karyawan yang ditandai dengan nilai thitung $(2,994)>t_{\text {tabel }}(1,658)$ dan angka signifikansi $0,004<0,1$. Artinya semakin tinggi tingkat komitmen karyawan terhadap perusahaan maka kinerja karyawan akan semakin tinggi.

Salah satu yang dicari oleh organisasi adalah memiliki karyawan yang memiliki komitmen tinggi. Komitmen ini penting sekali, karena tanpa komitmen sepandai apapun karyawan itu akan kurang bermanfaat bagi perusahaan. Komitmen karyawan bisa diartikan sebagai sebagai sebuah ukuran kekuatan identifikasi karyawan terhadap tujuan dan nilai organisasi serta keterlibatan didalamnya. Komitmen organisasi karyawan PT. Supra Matra Abadi tergolong baik yang dibuktikan oleh rata-rata jawaban yang menginterpretasikan bahwa sebagian besar karyawan setuju terhadap pernyataan dalam variabel komitmen organisasi.

Hasil dari penelitian ini didukung oleh teori yang dikemukakan oleh Allen dan Meyer (dalam Sihombing, 2017) yang menyatakan bahwa dengan komitmen organisasi yang tinggi dapat memperkuat atau meningkatkan kinerja karyawan. Hasil penelitian ini juga sesuai dengan penelitian terdahulu Sukmawati dan Gani (2014) yang menyatakan bahwa secara parsial terdapat pengaruh positif komitmen organisasi terhadap kinerja karyawan. Semakin tinggi komitmen organisasi karyawan maka semakin tinggi pula kinerjanya.

\subsubsection{Pengaruh Kecerdasan Emosional, Kepuasan Kerja, dan Komitmen Organisasi terhadap Kinerja Karyawan}

Hasil penelitian ini menunjukkan bahwa kecerdasan emosional, kepuasan kerja dan komitmen organisasi terbukti membawa pengaruh positif dan signifikan terhadap kinerja karyawan PT. Supra Matra Abadi Aek Nabara Kabupaten Labuhanbatu. Hal tersebut dapat diketahui berdasarkan hasil uji $\mathrm{F}$ yang ditandai dengan nilai $F_{\text {hitung }}(55,231)>F_{\text {tabel }}(2,930)$ dengan taraf signifikansi $0,000<0,1$. Artinya semakin baik kecerdasan emosional, kepuasan kerja dan komitmen organisasi karyawan, semakin baik pula kinerjanya.

Selanjutnya bahwa antara kecerdasan emosional, kepuasan kerja, dan komitmen organisasi terhadap kinerja karyawan menunjukkan hubungan yang erat. Kinerja karyawan dapat dijelaskan oleh kecerdasan emosional, kepuasan kerja, dan komitmen organisasi sebesar $65,4 \%$. Sedangkan sisanya 34,6\% dijelaskan oleh faktor-faktor lain yang tidak diteliti oleh penelitian ini, misalnya lingkungan kerja, iklim kerja, kepemimpinan, dan lain sebagainya.

\section{KESIMPULAN DAN SARAN}

\subsection{Kesimpulan}

Berdasarkan hasil analisis yang telah dilakukan, maka penulis dapat mengambil beberapa kesimpulan sebagai berikut : 
1. Kecerdasan emosional berpengaruh positif dan signifikan terhadap kinerja karyawan pada PT. Supra Matra Abadi Aek Nabara Kabupaten Labuhanbatu, dimana nilai thitung $(6,235)>\mathrm{t}_{\text {tabel }}(1,658)$ dan angka signifikansi $0,000<0,1$.

2. Kepuasan kerja berpengaruh positif dan signifikan terhadap kinerja karyawan pada PT. Supra Matra Abadi Aek Nabara Kabupaten Labuhanbatu, dimana nilai thitung $(5,593)>$ $\mathrm{t}_{\text {tabel }}(1,658)$ dan angka signifikansi $0,000<0,1$.

3. Komitmen organisasi berpengaruh positif dan signifikan terhadap kinerja karyawan pada PT. Supra Matra Abadi Aek Nabara Kabupaten Labuhanbatu, dimana nilai thitung $(2,994)$ $>t_{\text {tabel }}(1,658)$ dan angka signifikansi $0,004<0,1$.

4. Kecerdasan emosional, kepuasan kerja dan komitmen organisasi secara simultan berpengaruh positif dan signifikan terhadap kinerja karyawan pada PT. Supra Matra Abadi Aek Nabara Kabupaten Labuhanbatu.

5. Kinerja karyawan dapat dijelaskan oleh kecerdasan emosional, kepuasan kerja, dan komitmen organisasi sebesar $65,4 \%$. Sedangkan sisanya 34,6\% dijelaskan oleh faktorfaktor lain yang tidak diteliti oleh penelitian ini, misalnya lingkungan kerja, iklim kerja, kepemimpinan, dan lain sebagainya.

\subsection{Saran}

Berdasarkan hasil penelitian dan evaluasi, maka saran yang dapat diberikan penulis adalah sebagai berikut :

1. Kepada perusahaan disarankan untuk tetap meningkatkan kecerdasan emosional karyawannya dengan memperhatikan faktor-faktor kecerdasan emosional seperti peningkatan keterampilan sosial karyawan dengan mengadakan pelatihan, dan peningkatan motivasi yang diberikan oleh atasan.

2. Kepada perusahaan perlu memperhatikan lebih memperhatikan tingkat gaji yang diberikan kepada karyawan apakah sudah sesuai dengan beban pekerjaannya atau masih perlu ditingkatkan. Perusahaan juga perlu menyediakan jenjang karir yang jelas serta kesempatan promosi yang adil sesuai dengan prestasi yang telah diraih karyawan.

3. Kepada perusahaan disarankan untuk tetap meningkatkan komitmen organisasi karyawannya dengan memperhatikan faktor-faktor komitmen organisasi seperti menanamkan nilai-nilai perusahaan dalam diri karyawan melalui kegiatan sosial, outbond, family gatheting, dan lainnya.

4. Kepada pimpinan disarankan untuk memberikan dorongan kepada karyawan untuk meningkatkan keterampilan dan menciptakan rasa kebersamaan dalam perusahaan sehingga karyawan merasa nyaman dalam melaksanakan pekerjaannya.

5. Pihak manajemen perusahaan harus mampu menumbuhkan semangat kerja karyawan melalui pendekatan secara langsung oleh pimpinan yang sifatnya membina atau mengajak serta menjadi contoh bagi karyawan agar semangat kerja karyawan timbul dalam menyelesaikan tanggung jawabnya dalam pekerjaan sehingga dapat meningkatkan prestasi kerja mereka.

6. Bagi peneliti selanjutnya diharapkan agar dapat terus mengembangkan penelitian ini dengan menambah variabel lainnya sehingga dapat mengukur kinerja karyawan secara lebih mendalam.

\section{DAFTAR PUSTAKA}

Florida, Deasly. 2014. "Pengaruh Kecerdasan Emosional, Komitmen Organisasi, dan Kepuasan Kerja Terhadap Kinerja Karyawan (Perawat) di RSUP. DR. Soeradji Titronegoro Klaten”. Jurnal Psyco Idea, Volume 12, Nomor 1. 
Kuncoro, Mudrajat. 2009. Metode Riset untuk Bisnis dan Ekonomi. Jakarta : Erlangga.

Mangkunegara, Anwar Prabu. 2013. Manajemen Sumber Daya Manusia Perusahaan. Bandung : Remaja Rosdakarya.

Robbins, Stephen P dan Coulter, Mary. 2010. Manajemen. Jilid 1 Edisi 10. Cetakan Keempat. Jakarta : Erlangga.

Sedarmayanti. 2011. Manajemen Sumber Daya Manusia: Reformasi Birokrasi, dan Manjemen Pegawai Negeri Sipil. Cetakan Kelima. Bandung : Refika Aditama.

Situmorang, Syafrizal Helmi dan Muslich Lutfi. 2012. Analisis Data Untuk Riset Manajemen Dan Bisnis. Edisi 2. Medan : USU Press.

Sugiyono. 2012. Metode Penelitian Bisnis. Bandung : Alfabeta.

Sutrisno, Edy. 2010. Manajemen Sumber Daya Manusia. Jakarta : Kencana.

Sihombing, Inez Ivana. 2017. "Pengaruh Kecerdasan Emosional, Kepuasan Kerja dan Komitmen Organisasional Terhadap Kinerja Karyawan PT. Perkebunan Nusantara III (Persero) Medan". Skripsi. FEB USU. Medan.

Sukmawati dan Gani, Nurjaya. 2014. "Pengaruh Kecerdasan Emosional, Kepuasan Kerja, dan Komitmen Organisasi Terhadap Kinerja Karyawan Pada Kopersasi Karyawan PT. Telkom Siporennu Makassar". Jurnal Manajemen dan Akuntansi, Volume 3, Nomor 3 , hal 15.

Wibowo. 2012. Manajemen Kinerja. Jakarta : PT. Raja Grafindo Persada.

Wirawan. 2010. Konflik dan Manajemen Konflik. Jakarta : Salemba Humanika.

Wijaya, Tony, (2013). Metodologi Penelitian Ekonomi dan Bisnis Teori dan Praktik, Yogyakarta: Graha Ilmu. 